УДК 902.66

DOI 10.25205/1818-7919-2018-17-3-39-56

\author{
В. И. Молодин ${ }^{1,2}$, С. Райнхольд ${ }^{3}$, Л. Н. Мыльникова ${ }^{1,2}$ \\ Д. А. Ненахов ${ }^{1}$, С. Хансен ${ }^{3}$ \\ ${ }^{1}$ Институт археологии и этнографии СО РАН \\ пр. Академика Лаврентьева, 17, Новосибирск,630090, Россия \\ ${ }^{2}$ Новосибирский государственный университет \\ ул. Пирогова, 1, Новосибирск, 630090, Россия \\ ${ }^{3}$ Германский археологический институт, Евразийское отделение \\ Им Доль, 2-6, строение II, 14195, Берлин, Германия \\ molodin@archaeology.nsc.ru,sabine.reinhold@dainst.de,l.mylnikova@yandex.ru \\ nenaxoffsurgut@mail.ru,sekretariat.eurasien@dainst.de

\section{РАДИОУГЛЕРОДНЫЕ ДАТЫ НЕОЛИТИЧЕСКОГО КОМПЛЕКСА ПАМЯТНИКА ТАРТАС-1 (РАННИЙ НЕОЛИТ В БАРАБЕ) *}

В последнее десятилетие в Барабинской лесостепи выявлены памятники неолита с комплексами плоскодонной посуды. Первооткрыватели отнесли материалы памятника Автодрома- $2 / 2$ к боборыкинской культуре. На многослойном памятнике Тартас-1 изучен неолитический комплекс, состоящий из двух конструкций (жилищ?) и системы ям для хранения рыбы (и мяса птицы) с аналогичной керамикой. Подобные изделия зафиксированы и на памятнике Венгерово-2. Серия радиоуглеродных дат получена из объектов памятника Тартас-1 и одна дата - из Венгерово-2. Все датировки образцов укладываются в пределы VII тыс. до н. э., включая рубежи VI и VIII тыс. до н. э. На основе их анализа можно говорить о существовании в Барабе и в лесостепном правобережном Прииртышье не известного ранее периода неолита - раннего неолита. Его колорит проявляется в наличии оригинальной плоскодонной керамической посуды, орнаментации и технологии. Отнесение тартасских комплексов с плоскодонной керамикой к периоду раннего неолита не позволяет связывать их с боборыкинской культурой. Постулируется автохтонное происхождение тартасских комплексов.

Ключевые слова: Барабинская лесостепь, ранний неолит, плоскодонная посуда, радиоуглеродное датирование.

Данную статью авторы посвящают крупному отечественному ученому, археологу, историку, педагогу, организатору науки, доктору исторических наук - Николаю Ивановичу Дроздову, которому недавно исполнилось 70 лет. В круг его основных научных интересов входят, главным образом, проблемы палеолита. Однако ему всегда были интересны вопросы, касающиеся и более поздних культур периода голоцена. Профессор Н. И. Дроздов всегда тесно взаимодействовал с Институтом археологии и этнографии СО РАН. Он принимал самое деятельное участие в организации и проведении охранно-спасательных работ, особенно в районах строительства каскада круп-

\footnotetext{
* Исследование проведено в рамках Программы ХІІ.186.2. Проект № 0329-2018-0003 «Историко-культурные процессы в Сибири и на сопредельных территориях».

Молодин В. И., Райнхольд С., Мыльникова Л. Н., Ненахов Д. А., Хансен С. Радиоуглеродные даты неолитического комплекса памятника Тартас-1 (ранний неолит в Барабе) // Вестн. НГУ. Серия: История, филология. 2018. Т. 17, № 3: Археология и этнография. С. 39-56.
}

ISSN $1818-7919$

Вестник НГУ. Серия: История, фрилология. 2018. Том 17, № 3: Археология и этнография

() В. И. Молодин, С. Райнхольд, Л. Н. Мыльникова, Д. А. Ненахов, С. Хансен, 2018 
нейших гидроэлектростанций на Ангаре, в зонах затопления Усть-Илимской и Богучанской ГЭС, где раскопки производились на археологических памятниках практически всех эпох, включая этнографическую современность. Крайне важно, что сотни местонахождений были открыты и исследованы экспедицией, возглавляемой ученым, но еще и то, что полученные материалы активно вводились в научный оборот (см., например: [Васильевский и др., 1988]. Не случайно, именно в Красноярске была создана одна из первых совместных внешних структур ИАЭТ СО РАН - «Лаборатория археологии и палеогеографии Средней Сибири», руководителем которой стал Николай Иванович. В золотой фонд не только отечественной, но и мировой археологии вошла найденная Н. И. Дроздовым на стоянке УстьКова, скульптурка мамонта, выполненная из бивня этого животного [Васильевский, Дроздов, 1983; 1988], представляющая замечательный образец палеолитического искусства. Немало работ в творчестве ученого посвящено и неолиту Восточной Сибири (см., например: [Дроздов, 1979; 1984; 1985] и др.). Поэтому проблематика, связанная с этой во многом еще загадочной эпохой, думается, не оставит юбиляра равнодушным.

Проблемы неолита Барабинской лесостепи всегда были в центре внимания специалистов. В текущем тысячелетии изучение неолитических поселений и могильников существенно обогатило науку новыми, порой совершенно неожиданными открытиями. К их числу относятся: обоснование версии существования на данной территории артынской культуры [Бобров, Марочкин, 2011; Бобров и др., 2010; 2017], в свое время выделенной Л. Л. Косинской [1982] в западных районах Сибири; исследование серии погребальных комплексов, датируемых развитым неолитом, с оригинальной погребальной практикой на памятниках Венгерово-2А [Молодин и др., 2016] и Автодром-1 [Бобров и др., 2015]; разработка на качественно новом уровне на основе материалов преимущественно неолитических поселений концепции историко-культурного развития популяций в регионе [Юракова, 2017]; открытие памятников с плоскодонной неолитической керамикой, отнесенных первооткрывателями в Барабинской лесостепи к комплексам боборыкинской культуры [Боб- ров и др., 2012; Бобров, Марочкин, 2013; Бобров, Юракова, 2014].

Впрочем, последний вывод, предложенный нашими кемеровскими коллегами, с самого начала вызывал у авторов этой работы серьезные сомнения, которые еще более укрепились с открытием и стационарными раскопками уникального поселенческого ансамбля на памятнике Тартас-1. Колебания мнений по поводу боборыкинской принадлежности данных материалов - как автодромовских, так и тартасских, усилились с получением серии радиоуглеродных дат в высокорейтинговой лаборатории Университета Гейдельберга (Германия). Предварительному анализу этих дат в контексте исследования материалов памятника Тартас-1 и посвящена данная работа. Детальный анализ материалов неолитического поселенческого комплекса Тартас-1 проведен в специальной работе (Молодин В. И., Хансен С., Мыльникова Л. Н., Ненахов Д. А., Райнхольд С., Ненахова Ю. Н., Нестерова М. С., Дураков И. А., Кобелева Л. С. «Ранненеолитический комплекс на памятнике Тартас-1. Культурно-хронологическое осмысление»), как мы надеемся, она скоро будет опубликована в Германии, однако с учетом популярности, которую в настоящее время получила проблема «боборыкинских комплексов» в Западной Сибири (см., например: [Зах, 1987; 2009; Бобров и др., 2012; Бобров, Марочкин, 2013; Бобров, Юракова, 2014; Мерц, 2014; 2015; Кирюшин Ю. Ф., Кирюшин К. Ю., 2016]), нам представляется чрезвычайно актуальным максимально оперативно ввести в научный оборот новейшие данные по хронологии. Такая цель тем более важна, что в настоящее время именно абсолютное датирование независимыми методами занимает ведущие позиции в хронологической диагностике археологических памятников, при этом радиоуглеродный метод является объективным и проверяемым.

Неолитический комплекс на разновременном и разнокультурном памятнике Тартас-1 (рис. 1) [Молодин и др., 2015] открыт в результате применения методики вскрытия площади объекта сплошными раскопами, прежде всего по данным магнитной съемки. При таком подходе исследовались не только погребальные ансамбли различных эпох и культур, но и объекты поселенческого и ритуального характера, которые 


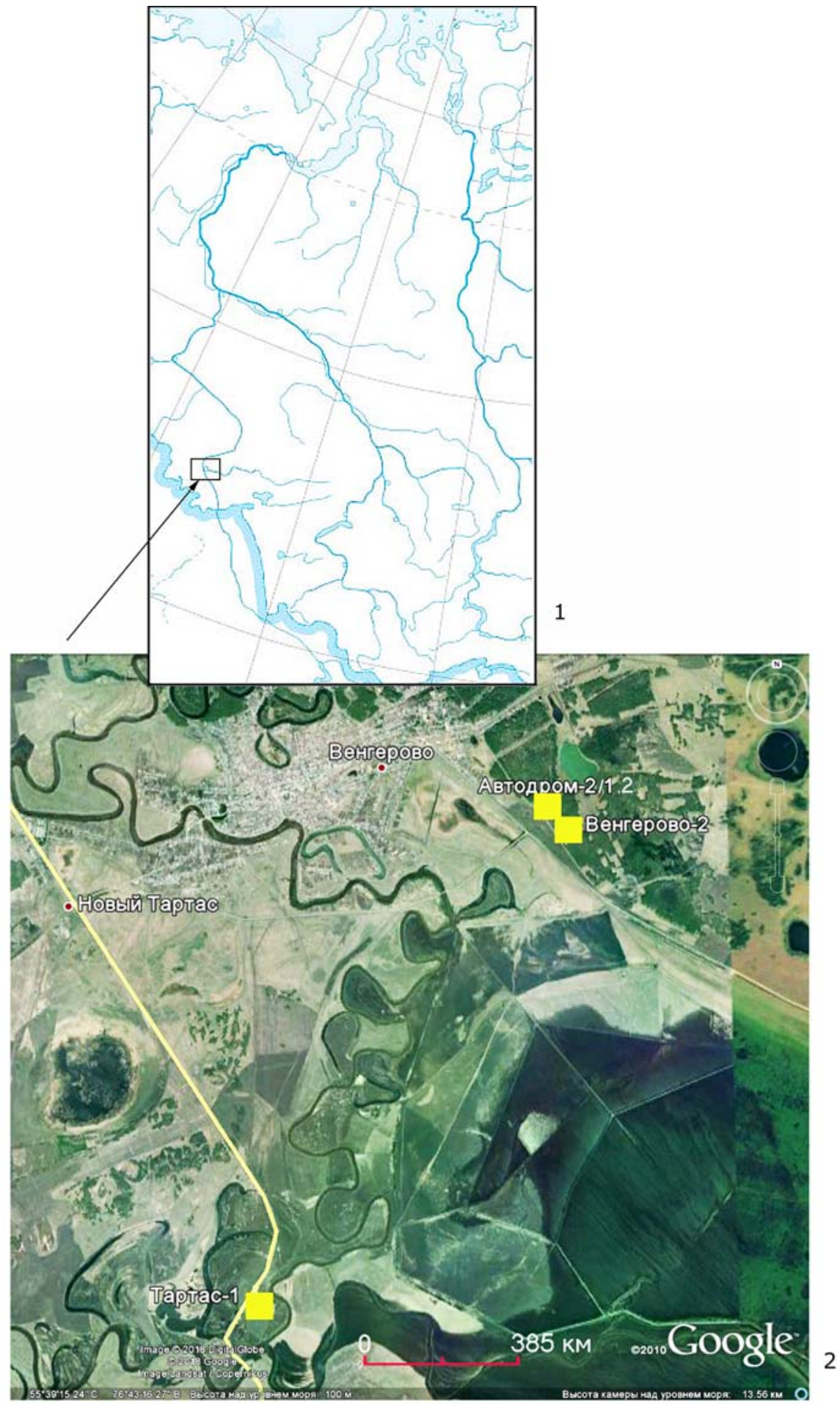

Puc. 1. Карта-схема расположения археологических памятников Тартас-1, Венгерово-2, Автодром-2/1, 2: 1 - на карте Западной Сибири; 2 - на карте Венгеровского археологического микрорайона

в ту или иную эпоху существовали на терpace, где расположен памятник. Терраса клином вдается в достаточно высокую для Барабинской лесостепи незатопляемую пойму. Поселенческий комплекс неолитической эпохи в настоящее время представлен двумя конструкциями с наличием столбовых ям от опоры кровли и стен, а также оригинальных очагов (рис. 2). Кроме того, выявлена система довольно глубоких и крупных в диа- 


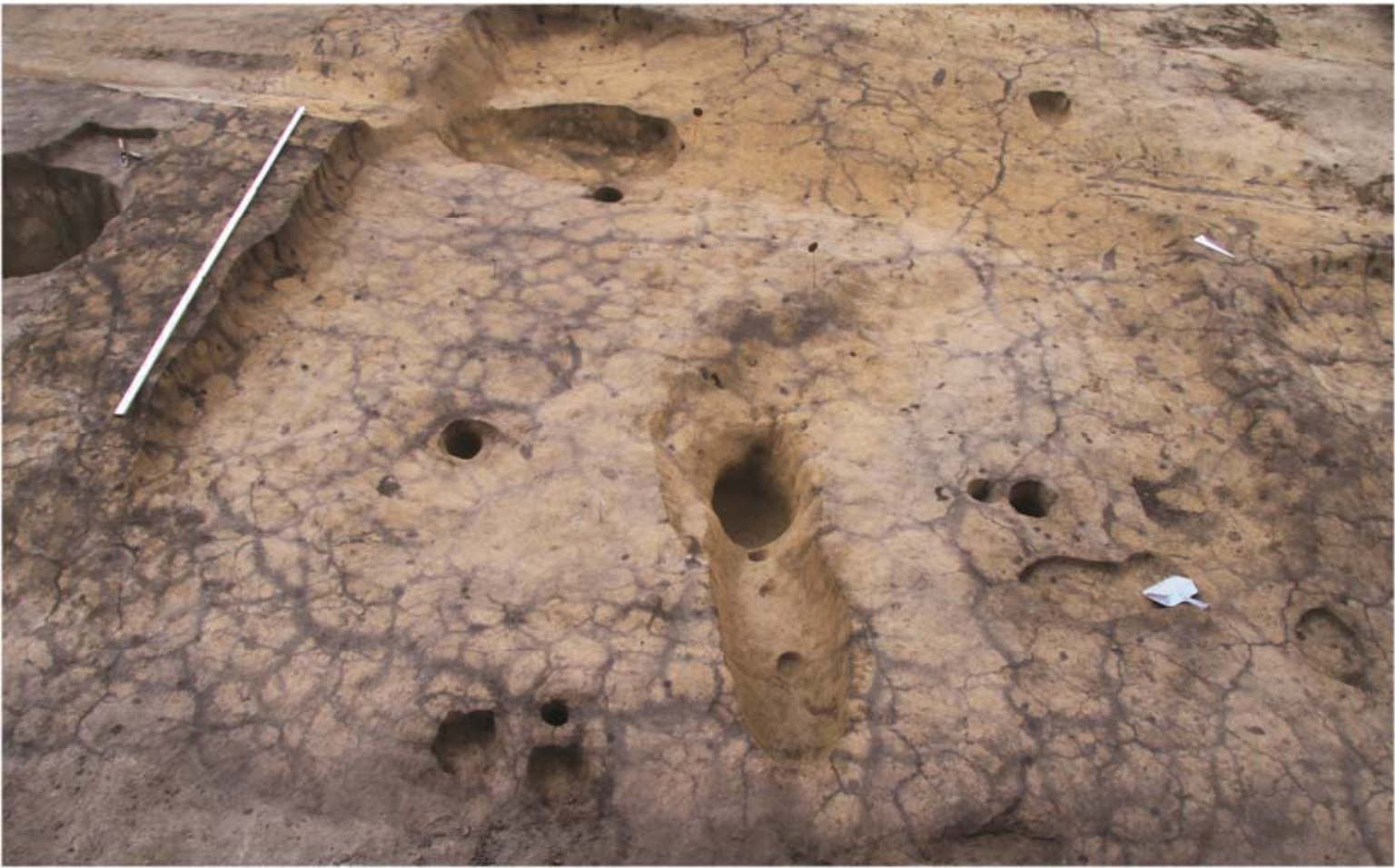

1

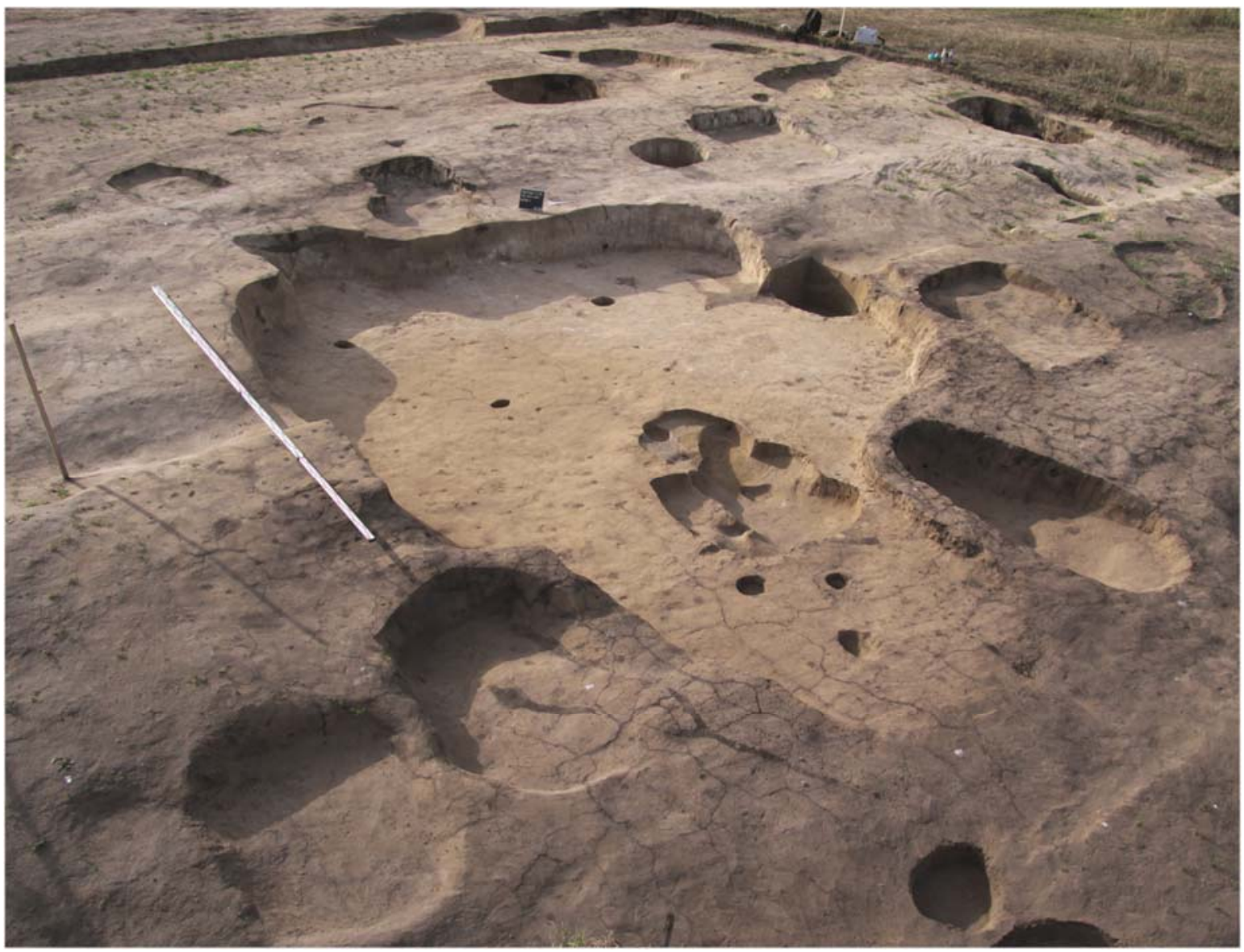

Puc. 2 (фото). Неолитический комплекс памятника Тартас-1:

1 - котлован конструкции № 6 (снято с Ю3); 2 - котлован конструкции № 7 (снято с В) 
метре ям, используемых, вероятно, для квашения рыбных запасов и водоплавающей дичи (рис. 3 ; 4). Очевидно, ямы имели и определенный сакральный смысл: в одной из них какое-то время обитала росомаха (лат. Gulo gulo), в другие были целенаправленно помещены трупы собаки (Canis), горностая (Mustela erminea), лисицы (Vulpes), зафиксированы также кости быка (Bovem) и овцы (козы?) (Capra). Одновременное бытование ям и хозяйственных сооружений неоднократно проявлялось стратиграфически (см. рис. 4). Выявлена периодичность их сооружения, функционирования и постепенной утраты функций. Благодаря четко выраженной планиграфии залегания хозяйственных отходов и инвентаря удалось также надежно зафиксировать горизонты обитания человека в самих конструкциях. В одной из них (№ 6) зарегистрировано использование теплотехнического сооружения в качестве коптильни для рыбы (см.: [Молодин и др., 2015]). Крайне важными являются стратиграфические наблюдения: неолитические объекты неоднократно (по меньшей мере четыре раза) (см. рис. 4) перекрывались погребальными сооружениями эпохи бронзы (андроновской (федоровской) культуры), относительно надежно, таким образом, датировав более древний комплекс. В заполнении жилых сооружений и ям были выявлены фрагменты керамики и три сосуда с устойчивой морфологией формы и орнаментики (рис. 5), выполненные по своеобразной технологии. Данная керамика абсолютно аналогична комплексу, впервые выявленному на памятнике Автодром-2/2 [Бобров и др., 2012; Бобров, Марочкин, 2013; Бобров, Юракова, 2014], который находится в пределах видимости с площади могильника Тартас-1. В 2015-2016 гг. проявления носителей данного культурного образования были зафиксированы при раскопках памятника кротовской культуры Венгерово-2, расположенного в непосредственной близости от Автодрома-2/2.

В итоге можно сказать, что мы имеем дело с ранее не известным в Барабе, да и вообще в лесостепном правобережном Прииртышье, культурным образованием неолита, колорит которого особенно отчетливо проявляется в оригинальной плоскодонной керамической посуде: в ее форме, орнаментации и технологии изготовления.

Действительно, имеющие место определенные черты сходства с посудой боборы-

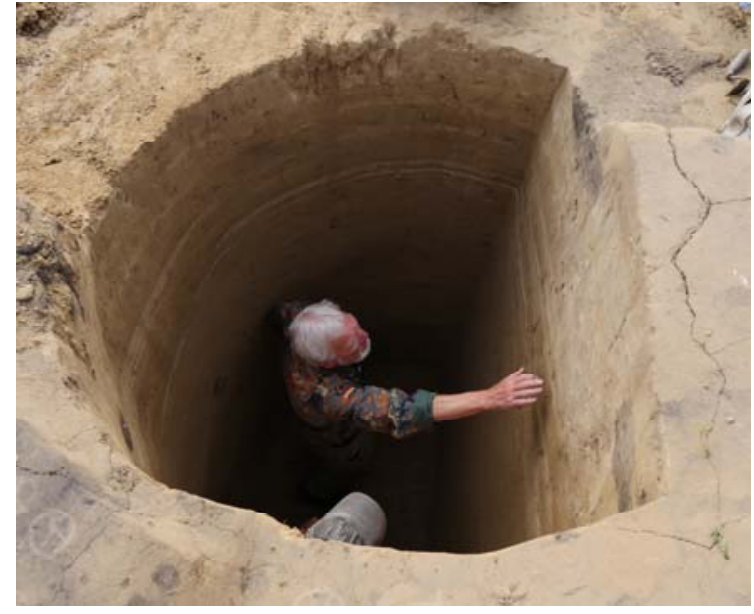

Puc. 3 (фото). Расчистка ямы для квашения рыбы на неолитическом комплексе памятника Тартас-1 (снято с В)

кинской культуры позволили В. В. Боброву и его коллегам, на основании материалов памятника Автодром-2 говорить о полном тождестве данных явлений, отнеся барабинские материалы к боборыкинской культуре, и даже показать вектор связей этих комплексов [Бобров, Марочкин, 2013].

По нашему мнению, такая интерпретация не верна. Проблема неолита с плоскодонной керамикой в Западной Сибири выглядит сегодня значительно сложнее и уже ставилась исследователями применительно к таежной зоне (см., например: [Гаджиева, 1993; Ковалева, 2008; Морозов, Стефанов, 1993; Стефанов, Борзунов, 2008; Ивасько, 2002; 2008; Косинская, 2010a; 2010б]). Детально проблема и ее решение разбирается нами в упомянутой выше работе. Суть ее сводится к автохтонному западносибирскому происхождению данного культурного образования, а столь ранние даты, полученные на тартасском поселении, ставят лесостепь едва ли не во главу угла этого явления.

В связи с вышесказанным значимость полученной на Тартасе серии дат трудно переоценить. Разумеется, и она нуждается в осмыслении, что мы и попытаемся сделать в настоящей статье.

Даты, о которых упоминается, получены по костям животных. Всего выполнено восемь измерений. Все образцы взяты из стратиграфически безупречных культурных горизонтов, поэтому получившаяся достаточно растянутая во времени шкала может говорить скорее о несовершенствах метода, чем 


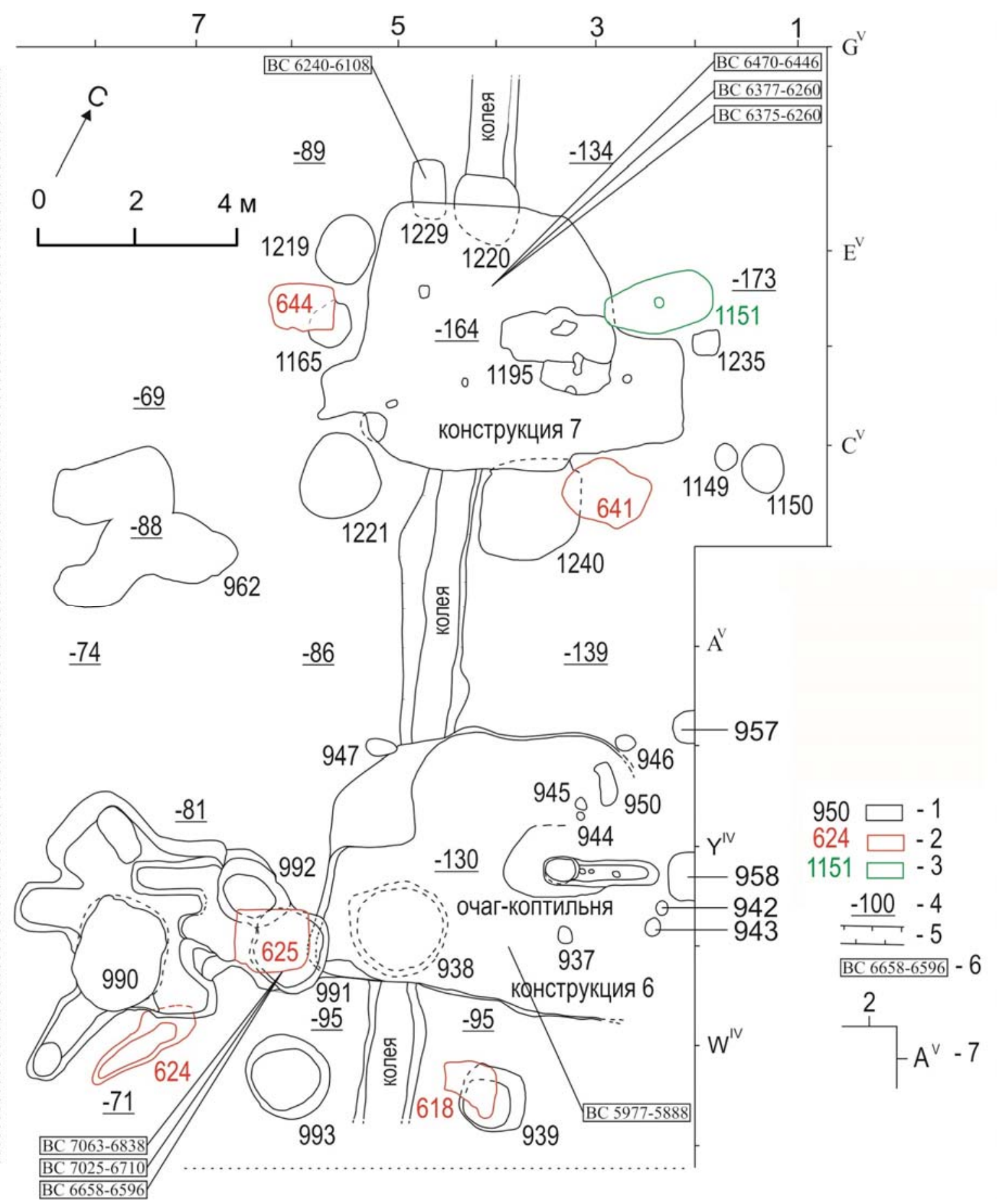

Puc. 4. План участка раскопа с неолитическим комплексом памятника Тартас-1: 1 - конструкции № 6 и 7, ямы эпохи неолита; 2 - погребения андроновской (федоровской) культуры; 3 - объекты эпохи бронзы; 4 - нивелировочные отметки; 5 - колея; 6 - дата по $\mathrm{C}^{14} ; 7$ - граница раскопа

о некорректном образце. В результате оказались датированными обе жилые (или производственные) конструкции, а также несколько сопутствующих им ям, связанных как с производственными, так, вероятно, и с ритуальными действиями.
Суммированная сводка результатов анализов неолитических комплексов тартасского памятника произведена по данным, представленным лабораторией Гейдельбергского университета (Германия). Оба паспорта (в них присутствуют не только датировки нео- 
литическаих объектов) подписаны доктором Ронни Фриедерихом (от 23.03.2016 и 30.01.2017, Project: Baraba-steppe, Tartas; Auftrag 150581 ; 160600) (табл. 1).

Наиболее ранними оказались три показателя, датирующие систему ям № 991 (MAMS 26158; MAMS 26157 и MAMS 26156) (рис. 6). Первый из них, полученный по кости из заполнения ямы, демонстрирует самую раннюю позицию. По sigma 1 она определяется в пределах 7063-6838 лет до н. э. С этой датой вполне коррелирует вторая из этой же системы (см. рис. 4; 6) - из кости росомахи, лежащей на дне ямы. По sigma 1 она определяется в пределах 7025-6710 лет до н. э. Третья датировка получена по кости собаки, взятой из средней части заполнения ямы № 991. По sigma 1 она попадает в пределы 6658-6596 лет до н. э. Интересно, что более древняя дата получена по кости, лежащей в верхней части заполнения ямы, а «молодая» - в средней. Однако если ориентироваться на sigma 2 (см. табл. 1; рис. 6), все три даты имеют точки соприкосновения.

Еще четыре даты (MAMS 29402; MAMS 29403; MAMS 29404 и MAMS 29407) демонстрируют весьма близкие показатели, а по sigma 2 - и коррелируют (рис. 6). Три первые даты определяют возраст горизонтов обитания конструкции 7. По sigma 1 первый горизонт демонстрирует показатели 64706446 лет до н. э.; второй горизонт обитания датируется возрастом 6477-6260 лет до н. э.; третий - в пределах 6375-6260 лет до н. э. Получается, что время существования горизонтов обитания 2 и 3 практически совпало. Любопытно, что показатель наиболее молодого (верхнего) горизонта обитания 1 продемонстрировал более древнее значение, что, впрочем, может легко объясняться механическим попаданием данного образца из нижних горизонтов во время функционирования конструкции.

Вполне коррелирует с указанной выше серией дата, полученная по кости из примыкающей к сооружению ямы № 1220 (см. рис. 4 ; 6). По sigma 1 образец датируется в пределах 6240-6108 лет до н. э. Несколько более молодую, однако созвучную с продемонстрированными выше, позицию показывает образец (MAMS 29405), взятый из заполнения жилища № 6. Его показатель по sigma 1 составил 5977-5888 лет до н. э. (см. рис. 4,6$)$.
Таким образом, все восемь образцов, взятых из исследованного комплекса, по времени находятся в пределах VII тыс. до н. э., касаясь рубежей VI и VIII тыс. до н. э. (см. рис. 6).

Имеющийся диапазон дат в пределах тысячелетия вновь демонстрирует хорошо известную проблему разброса радиоуглеродных датировок в границах одного комплекса, что объясняется целым набором неоднозначных для различных памятников, порой вообще труднообъяснимых явлений [Косинцев и др., 2004; Косинская, 2010а. С. 43], включающих, в том числе, и несовершенство метода. Все сказанное выше не должно смущать археологов. Очевидно, что этому методу определения хронологии принадлежит настоящее и будущее науки.

Важно отметить, что в обозначенных пределах оказался датированным «загадочный» объект, выявленный нашей экспедицией на памятнике Венгерово-2. Здесь, среди конструкций кротовской культуры эпохи бронзы было обнаружено сооружение в виде большой и глубокой ямы сложной конфигурации

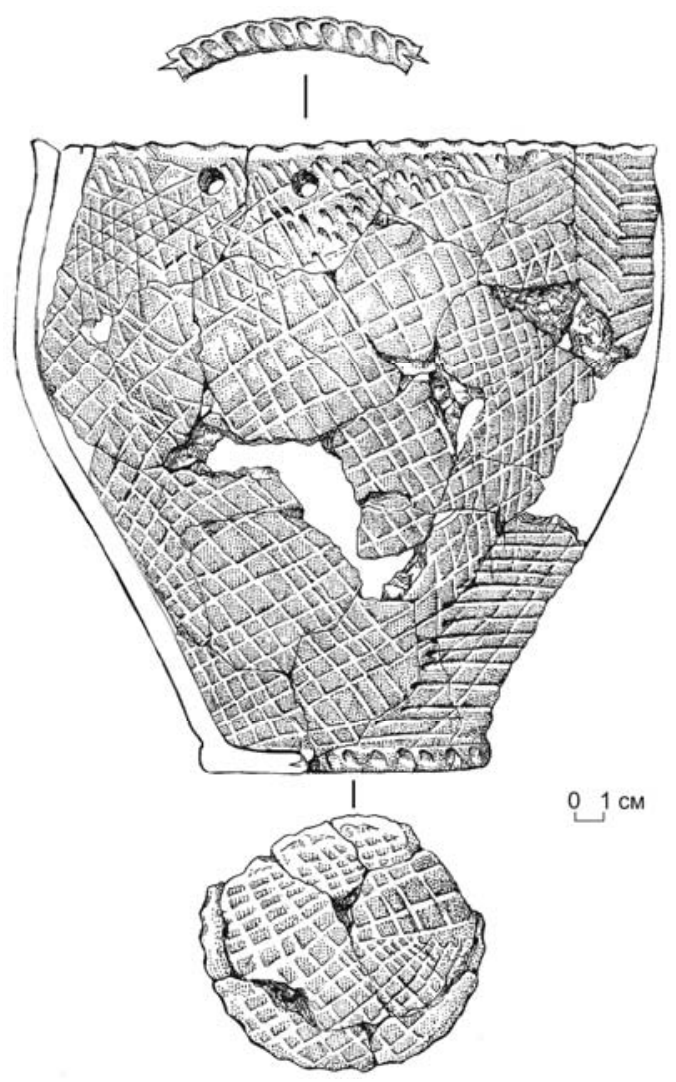

Puc. 5. Реставрированный сосуд из неолитического комплекса памятника Тартас-1 


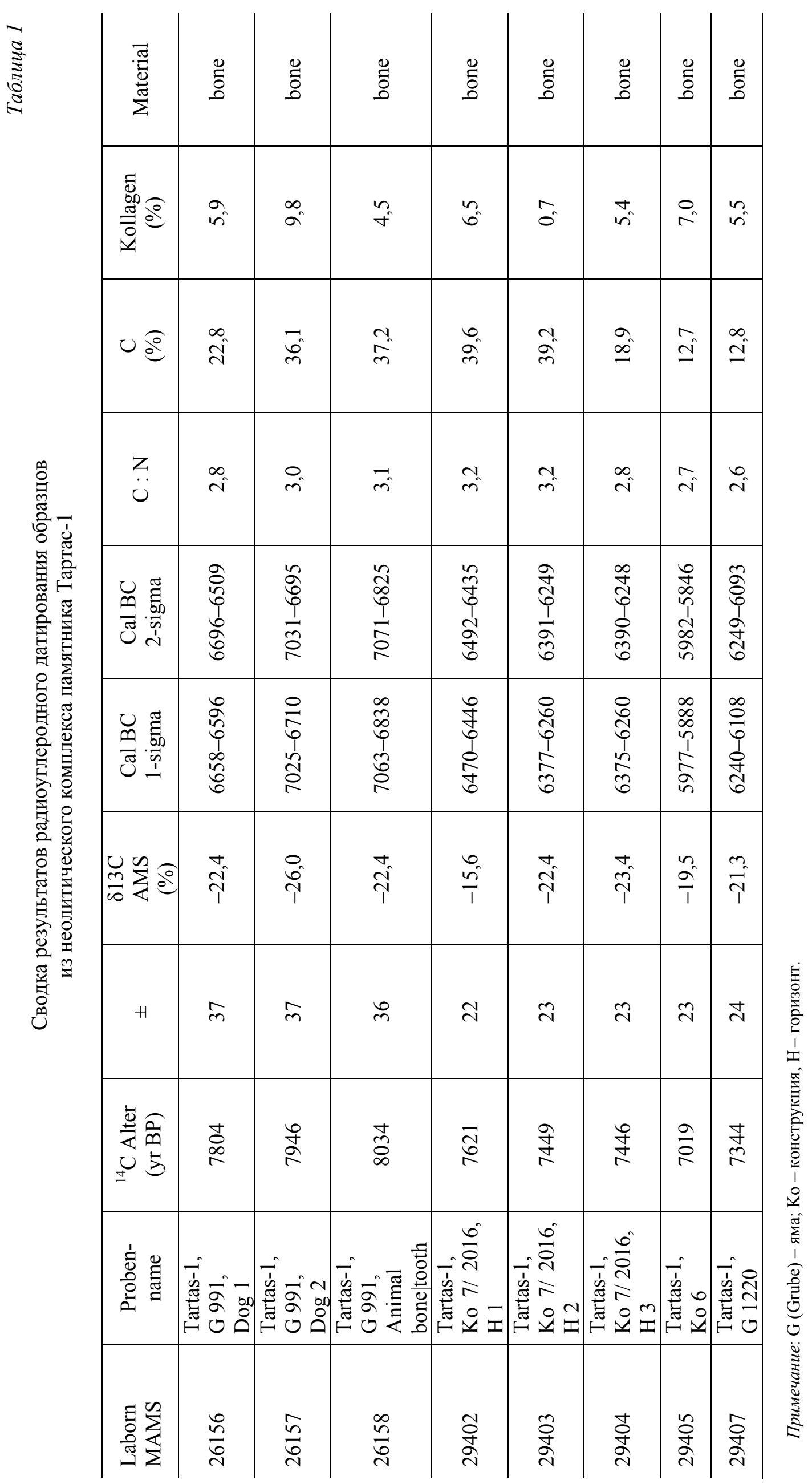




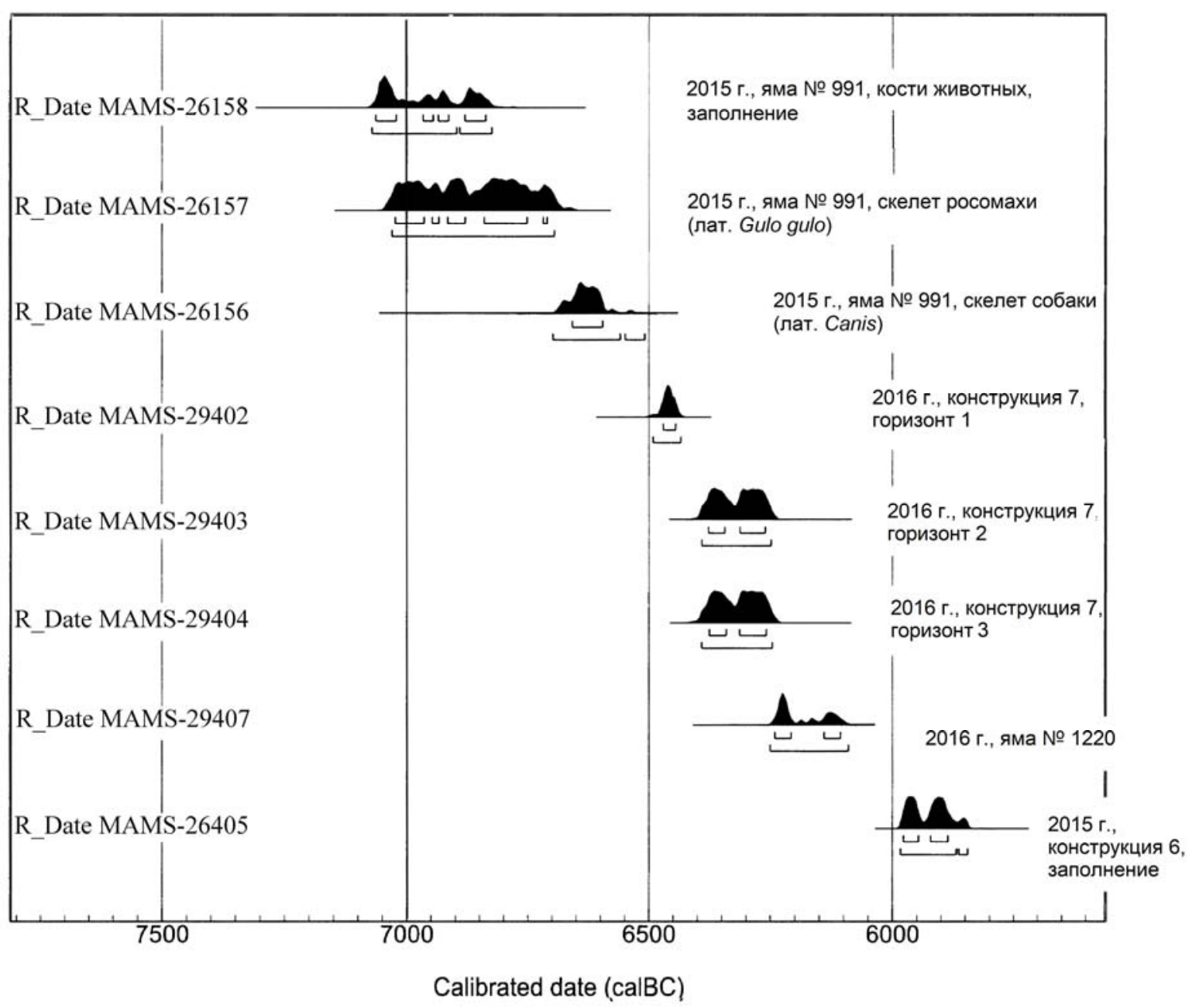

Puc. 6. Сводная характеристика радиоуглеродных дат, полученных на неолитических комплексах памятника Тартас-1 в 2015-2016 гг.

(двухкамерный котлован). В ее заполнении у дна помимо немногочисленных костей животных найден великолепный роговой гарпун (рис. 7). Взятый из ямы для радиоуглеродного анализа образец кости животного, индексированный как MAMS 29409, по sigma 1 датирован 6426-6385 лет до н. э., а по sigma 2 - 6440-6266 лет до н. э., что полностью совпадает со временем бытования анализируемого комплекса на Тартасе. Таким образом, получено еще и косвенное свидетельство датировки оригинальной плоскодонной неолитической керамики, фрагменты которой были выявлены и в пределах памятника Венгерово-2.

Между тем нельзя не отметить, что устойчивая серия радиоуглеродных дат, о которых шла речь, оказалась не сопоставима с датировками абсолютно аналогичной керамики из поселения Автодром- $2 / 2$, полученными прямым датированием [Мосин,
2015; 2016]. Три даты этого памятника демонстрируют возраст $5460 \pm 100,5967 \pm 100$, $5884 \pm 100$ ВР. Их калиброванные значения занимают промежуток с последней четверти VI до середины V тыс. до н. э. Учитывая тождественность плоскодонных керамических комплексов Тартас-1 и Автодрома-2/2, объяснений несоответствию дат может быть два.

Первое и наиболее вероятное - несовершенство метода прямого радиоуглеродного датирования керамических образцов. Втоpoe - возможность достаточно длительного обитания в Барабинской лесостепи в неолите носителей традиции изготовления плоскодонной посуды. Оба объяснения, разумеется, нуждаются в дополнительной проверке и аргументации.

Какое же культурно-хронологическое место занимает тартасский неолитический комплекс с плоскодонной посудой? Уже от- 


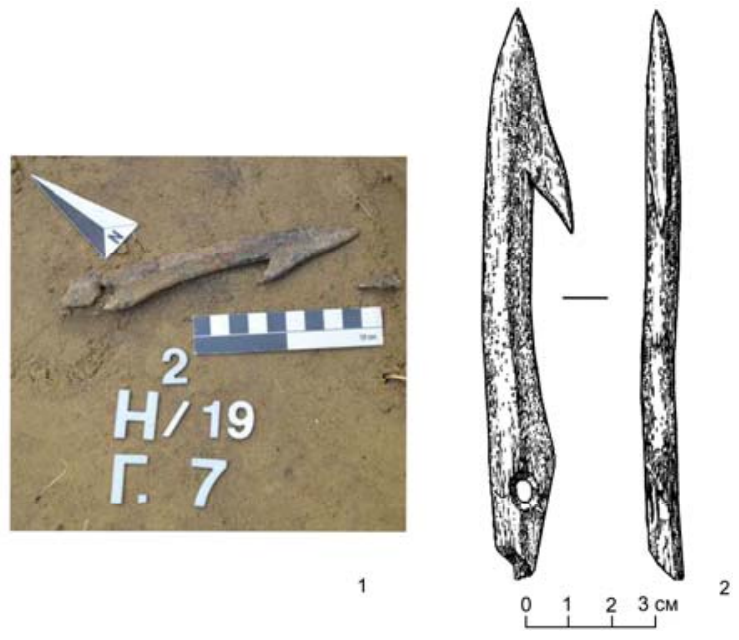

Puc. 7. Гарпун из рога с площади неолитического сооружения на поселении Венгерово-2: 1 - фото (снято с Ю3); 2 - прорисовка предмета

мечалось, что на территории Барабинской лесостепи и прилегающих районов Прииртышья наиболее ранние проявления человеческой деятельности относятся к финальной стадии плейстоцена и не уходят глубже пятнадцати тысяч лет от сегодняшнего дня [Окладников, Молодин, 1983; Генинг, Петрин, 1985; Петрин, 1986]. К мезолитической эпохе надежно относится лишь стоянка Черноозерье VI-VIa [Генинг и др., 1973. С. 24-47]. Представительная серия дат имеется с мезолитических памятников таежной зоны Западной Сибири. Так, хронология мезолитических стоянок на Конде определяется временем 9500-6700 л. н., при этом даты моложе 7000 л. н. могут считаться спорными [Тимофеев, Зайцева, 1997; Погодин, Беспрозванный, 1999; Беспрозванный, Погодин, 2006].
Опорной для определения границы мезолита и неолита можно принять серию калиброванных датировок, полученных благодаря работам Л. Л. Косинской на памятнике Харампур-4 (табл. 2). По-видимому, данные параметры можно экстраполировать и на более южные, в том числе лесостепные районы Западной Сибири.

Имеющаяся на данный момент серия радиоуглеродных дат с памятников эпохи неолита Барабы не так уж велика. Она получена в разных лабораториях. В целом калиброванные даты укладываются в пределы V первой половины IV тыс. до н. э. (см.: [Mарченко, 2009а; 2009б]. Из всего сказанного следует, что рассматриваемый в работе неолитический комплекс памятника Тартас-1 с плоскодонной посудой относится к его наиболее ранней стадии и может быть квалифицирован как ранний неолит Барабы. Важно, что этот вывод совпадает с хронологической оценкой неолитических памятников западносибирского Севера. Так, калиброванные радиоуглеродные даты помещают группу ранненеолитических памятников в пределы конца VII - первой половины VI тыс. до н. э. Вторая группа памятников - VI - середина V тыс. до н. э., датирована исследователями средней стадией неолита [Косинская, 2010а. С. 43; 2014].

Подчеркнем и то обстоятельство, что к наиболее ранней стадии отнесены комплексы с плоскодонной посудой, интерпретированные как поселения кошкинской культуры [Косинская, 2010а]. Плоскодонная керамика обнаружена и на поселении Барсова Гора II/9 [Чемякин, 2009; 2011]. Как отмечает Л. Л. Косинская, жилища 15 и 16 датируются в пределах раннего неолита 1, а жилище 7

Таблий 2

Радиоуглеродные даты памятника Харампур-4

\begin{tabular}{|c|c|c|}
\hline \multirow[b]{2}{*}{ Шифр образца } & \multicolumn{2}{|c|}{ Возраст } \\
\hline & $\begin{array}{c}\text { некалиброванный } \\
\text { (ВР) }\end{array}$ & $\begin{array}{c}\text { калиброванный } \\
\text { (ВС) }\end{array}$ \\
\hline Ле-7789 & $7810 \pm 110$ & $\begin{array}{l}6820-6490(68,2 \%) \\
7050-6450(95,4 \%)\end{array}$ \\
\hline Ле-7790 & $7720 \pm 250$ & $\begin{array}{l}7050-6350(68,2 \%) \\
7300-6000(95,4 \%)\end{array}$ \\
\hline Ле-7791 & $8200 \pm 150$ & $\begin{array}{l}7460-7050(68,2 \%) \\
7550-6700(95,4 \%)\end{array}$ \\
\hline Лe-7792 & $8200 \pm 200$ & $\begin{array}{l}6950-6850(68,2 \%) \\
7600-6650(95,4 \%)\end{array}$ \\
\hline
\end{tabular}


относится к раннему неолиту 2 (по ее периодизации) [Косинская, 2014. С. 35]. Поэтому неолит Западной Сибири (таежной и лесостепной зоны) с плоскодонной керамикой следует оценивать как явление общеисторического и стадиального характера, в основе, вероятно, автохтонного. Отнесение тартасских комплексов с плоскодонной керамикой, как и отмеченных выше из таежной зоны Западной Сибири (по крайней меpe - амнинских [Морозов, Стефанов, 1993; Стефанов, Борзунов, 2008] и каюковских [Ивасько, 2002; 2008]), к раннему неолиту не позволяет связывать их с боборыкинской культурой хотя бы по той причине, что последняя по времени значительно моложе (см.: [Ковалева, Зырянова, 2008; Выборнов и др., 2014]), чем предыдущие образования [Косинская, 2014].

За автохтонную версию происхождения образований с посудой с плоским дном западносибирского Севера от местного мезолита, высказанную Л. Л. Косинской [2010а], говорит, прежде всего, сопряженность дат, а также и некоторые другие черты, например эволюция технологии каменной индустрии и домостроительства [Косинская, 2010б]. Сходные явления могли быть и в Барабинской лесостепи, но предшествующий (мезолитический) период здесь пока слабо изучен. Тем не менее известные в настоящее время данные по верхнепалеолитическим памятникам как будто не противоречат этой версии.

Думается, что малоперспективно искать истоки прихода носителей культуры с плоскодонными формами посуды откуда-то с запада, где подобная керамика есть в неолите лесостепного и степного Поволжья [Выборнов, 2008], тем более с территории российского Дальнего Востока [Окладников, Медведев, 1983]. Центры с древнейшей, плейстоценовой, керамикой в настоящее время в мире обозначены [Jordan et al., 2016. Fig. 94]. Но и они явно свидетельствуют о том, что человечество пришло к изобретению глиняной посуды далеко не одновременно, и это явление не связано с миграциями, по крайней мере континентального или глобального характера.

Однако версию культурогенеза носителей традиции изготовления плоскодонной керамики в Барабе, как отмечено выше, предполагается детально рассмотреть в специальной работе.

\section{Список литературы}

Беспрозванный Е. М., Погодин А. А. Мезолит севера Западной Сибири: итоги изучения // Современные проблемы археологии России: Материалы Всерос. археологического съезда. Новосибирск: Изд-во ИАЭТ CO PAH, 2006. T. 1. C. 168.

Бобров В. В., Марочкин А. Г. Артынская культура // Труды III (XIX) Всероссийского археологического съезда. СПб.; М.; Великий Новгород, 2011. Т. 1. С. 106-108.

Бобров В. В., Марочкин А. Г. Боборыкинский комплекс из Барабы: проблема исторической интерпретации // Вестн. Томск. гос. ун-та. История. 2013. № 3 (23). С. 211-215.

Бобров В. В., Марочкин А. Г., Юракова А. Ю. Керамика артынской поздненеолитической культуры (по материалам поселения Автодром-2) // Культура как система в историческом контексте: опыт Западно-Сибирских археолого-этнографических совещаний. Томск: Аграф-Пресс, 2010. С. 113116.

Бобров В. В., Марочкин А. Г., Юракова А. Ю. Поселение боборыкинской культуры Автодром-2/2 (северо-западные районы Барабинской лесостепи) // Вестн. археологии, антропологии и этнографии. 2012. № 3 (18). C. 4-13.

Бобров В. В., Марочкин А. Г., Юракова А. Ю. Исследования поселенческих и погребальных комплексов эпохи неолита на памятнике Автодром-1 в Барабинской лесостепи в 2015 году // Проблемы археологии, этнографии, антропологии Сибири и сопредельных территорий. Новосибирск: Изд-во ИАЭТ СО РАН, 2015. Т. 22. С. 7-11.

Бобров В. В., Марочкин А. Г., Юракова А. Ю. Поселение артынской культуры Автодром-2 - памятник позднего неолита в Барабинской лесостепи // Археология, этнография и антропология Евразии. 2017. Т. 45, № 1. C. 49-61.

Бобров В. В., Юракова А. Ю. Боборыкинский комплекс в неолите Барабинской лесостепи // Труды IV (XX) Всероссийского археологического съезда в Казани. Казань: Отечество, 2014. Т. 1. С. 211-214.

Васильевский Р. С., Бурилов В. В., Дроздов Н. И. Археологические памятники Северного Приангарья. Новосибирск: Наука, 1988. C. 225.

Васильевский Р. С., Дроздов Н. И. Палеолитические скульптурные изображения из 
Восточной Сибири // Пластика и рисунки древних культур. Новосибирск: Наука, 1983. C. 59-65.

Васильевский Р. С., Дроздов Н. И. Скульптурка мамонта из Северного Приангарья // Природа. 1988. № 4. С. 46-48.

Выборнов А. А. Неолит Волго-Камья. Самара: Изд-во Самар. гос. пед. ун-та, 2008. $490 \mathrm{c}$.

Выборнов А. А., Мосин В. С., Епимахов $A$. B. Хронология Уральского неолита // Археология, этнография и антропология Евразии. 2014. № 1 (57). С. 33-48.

Гаджиева E. A. Неолит бассейна р. Конды: Автореф. дис. ... канд. ист. наук. СПб., 1993. $18 \mathrm{c}$.

Генинг В. Ф., Петрин В. Т. Позднепалеолитическая эпоха на юге Западной Сибири. Новосибирск: Наука, 1985. 88 с.

Генинг В. Ф., Петрин В. Т., Косинская Л. Л. Первые поселения эпохи позднего палеолита и мезолита в Западной Сибири // Из истории Сибири. Томск: Изд-во ТГУ, 1973. Вып. 5. С. 24-47.

Дроздов Н. И. Палеографические и экологические условия жизни человека в Северном Приангарье в конце плейстоцена-голоцена // Особенности естественно-географической среды и исторические процессы в Западной Сибири. Томск: Изд-во ТГУ, 1979. C. 31-34.

Дроздов Н. И. Проблемы и перспективы археологического изучения бассейна Северного Енисея и Северной Ангары // Проблемы исследования каменного века Евразии. Красноярск: Изд-во Краснояр. гос. пед. ун-та, 1984. С. 10-14.

Дроздов Н. И. Современное состояние и возможности различия стратиграфии голоцена в Северном Приангарье // Природа и хозяйство Красноярского края. Красноярск: Издво Краснояр. гос. пед. ун-та, 1985. С. 36-39.

3ax B. A. К вопросу о боборыкинской культуре // Роль Тобольска в освоении Сибири. Тобольск, 1987. С. 11-13.

3ax B. A. Хроностратиграфия неолита и раннего металла лесного Тоболо-Ишимья. Новосибирск: Наука, 2009. 320 с.

Ивасько Л. В. Укрепленное поселение каменного века Каюково-2 // Материалы и исследования по истории Северо-Западной Сибири. Екатеринбург: Изд-во Урал. гос. ун-та, 2002. С. 7-25.
Ивасько Л. В. О каюковской археологической культуре // Барсова Гора: древности таежного Приобья. Екатеринбург; Сугрут: Урал. кн. изд-во, 2008. С. 112-122.

Кирюшин Ю. Ф., Кирюшин К. Ю. Керамика боборыкинского облика с поселений юго-западных районов Алтайского края // Теория и практика археологических исследований. Барнаул: Изд-во АлтГУ, 2016. № 2 (14). C. 7-23.

Ковалева В. T. Поселение Сумпанья III и проблема культурно-хронологической атрибуции памятников кошкинского типа в таежной зоне Западной Сибири // Барсова Гора: древности таежного Приобья. Екатеринбург; Сугрут: Урал. кн. изд-во, 2008. C. $123-134$.

Ковалева В. Т., Зырянова С. Ю. К вопросу о сатыгинском типе керамики // Барсова Гора: древности таежного Приобья. Екатеринбург; Сугрут: Урал. кн. изд-во, 2008. C. $135-145$.

Косинская Л. Л. Поздненеолитическая стоянка Артын на Среднем Иртыше // Археологические исследования Севера Евразии. Свердловск: Изд-во Урал. гос. ун-та, 1982. С. 18-27.

Косинская Л. Л. Глава 1. Археологические культуры Ямала. 1.1. Каменный век севера Западной Сибири // История Ямала. Екатеринбург: Изд-во Баско, 2010а. Т. 1: Ямал традиционный, кн. 1: Древние культуры и коренные народы. С. 22-47.

Косинская Л. Л. Сырьевая стратегия и камнеобработка как аспекты культурной адаптации (по материалам неолитических памятников севера Западной Сибири) // Уральский исторический вестник. 2010б. № 2 (27). C. 13-25.

Косинская Л. Л. Ранняя гребенчатая керамика в неолите Зауралья // Уральский исторический вестник. 2014. № 2 (43). С. 30-39.

Косинщев П. А., Бобковская Н. Е., Беспрозванный E. M. Радиоуглеродная хронология археологических памятников таежной зоны Западной Сибири // Ханты-Мансийский автономный округ в зеркале прошлого. Томск; Ханты-Мансийск: Изд-во ТГУ, 2004. Вып. 2. C. 17-32.

Марченко Ж. В. Радиоуглеродная хронология археологических памятников эпохи неолита и раннего металла Барабинской лесостепи // Роль естественно-научных мето- 
дов в археологических исследованиях. Барнаул: Изд-во АлтГУ, 2009а. С. 140-143.

Марченко Ж. В. Культурная принадлежность, хронология и периодизация археологических памятников среднего течения $\mathrm{p}$. Тары (эпоха неолита и бронзы): автореф. дис. ... канд. ист. наук. Новосибирск, 2009б. $26 \mathrm{c}$.

Мери B. K. Боборыкинский комплекс поселения Борлы (Северо-Восточный Казахстан) // Труды IV (XX) Всероссийского археологического съезда в Казани. Казань: Отечество, 2014. Т. 1. С. 297-301.

Мери В. К. О керамике боборыкинского типа из неолит-энеолитических комплексов Северного Казахстана // Древний Тургай и Великая степь: часть и целое. Сборн. Статей, посвящ. 70-летию В. Н. Логвина. Костанай; Алматы: Изд-во Инст. археологии им. Маргулана, 2015. С. 267-272.

Молодин В. И., Ненахов Д. А., Нестерова М. С., Дураков И. А., Васильев С. К. Оригинальный производственный комплекс на Тартасе-1 (Барабинская лесостепь) // Проблемы археологии, этнографии, антропологии Сибири и сопредельных территорий. Новосибирск: Изд-во ИАЭТ СО РАН, 2015. T. 21. С. 326-331.

Молодин В. И., Нестерова М. С., Мыльникова Л. Н. Погребальные комплексы эпохи неолита Венгерово-2А (юг Западно-Сибирской равнины): результаты мультидисциплинарных исследований // Археология, этнография и антропология Евразии. 2016. T. 44, № 2. С. 30-46.

Морозов В. М., Стефанов В. И. Амня-1древнейшее городище Северной Евразии? // Вопросы археологии Урала. Екатеринбург: Изд-во Урал. гос. ун-та, 1993. Вып. 21. C. 161-163.

Мосин В. С. Неолит лесостепного Зауралья и Прииртышья: новейшие исследования и периодизация // Вестн. Кем. гос. ун-та. 2015. № 2 (62). С. 108-113.

Мосин В. С. Социокультурное пространство в позднем каменном веке // Вестн. Перм. гос. ун-та. История. 2016. Вып. 1 (32). C. 19-27.

Окладников А. П., Медведев В. Е. Исследование многослойного поселения Гася на Нижнем Амуре // Изв. Сибирского отделения АН СССР. Серия общественных наук, 1983. Вып. 1, № 1. С. 93-97.
Окладников А. П., Молодин В. И. Палеолит Барабы // Палеолит Сибири. Новосибирск: Наука, 1983. С. 101-106.

Петрин В. T. Палеолитические памятники Западно-Сибирской равнины. Новосибирск: Наука, 1986. 142 с.

Погодин А. А., Беспрозванный Е. М. Новые исследования каменного века таежной зоны Западной Сибири // 120 лет археологии восточного склона Урала. Первые чтения памяти В. Ф. Генинга. 42 новейшие открытия уральских археологов. Екатеринбург: Изд-во Урал. гос. ун-та, 1999. С. 99-103.

Стефанов В. И., Борзунов В. А. Неолитическое городище Амня I (по материалам раскопок 1993 и 2000 годов // Барсова Гора: древности таежного Приобья. Екатеринбург; Сугрут: Урал. кн. изд-во, 2008. C. 105-107.

Тимофеев В. И., Зайцева Г. И. К проблеме радиоуглеродной хронологии неолита степной и юга лесной зоны европейской части России (обзор источников) // Радиоуглерод и археология. СПб., 1997. Вып. 2. С. 98-108.

Чемякин Ю. П. Охранные раскопки на поселении Барсова Гора II/9, или Двадцать лет спустя // Ханты-Мансийский автономный округ в зеркале прошлого. Томск; Ханты-Мансийск: Изд-во ТГУ, 2009. С. 198-213.

Чемякин Ю. П. Радиоуглеродные даты памятников Барсовой Горы // Вопросы археологии Урала. Екатеринбург; Сургут: Магеллан, 2011. Вып. 26. С. 247-249.

Юракова А. Ю. Неолит Барабинской лесостепи и южно-таежного Прииртышья: Автореф. дис. ... канд. ист. наук. Кемерово, 2017. $30 \mathrm{c}$.

Jordan P., Gibbs K., Hommel P., Piezonka H., Silva F., Steele J. Moddeling the diffusion of pottery technologies across AfroEurasia: emerging insights and future research // Antiquity. 2016. № 90351. P. 590-603. 


\author{
V. I. Molodin ${ }^{1,2}$, S. Reinhold ${ }^{3}$, L. N. Mylnikova ${ }^{1,2}$, \\ D. A. Nenakhov ${ }^{1}$, S. Hansen ${ }^{3}$ \\ ${ }^{1}$ Institute of Archaeology and Ethnography SB RAS \\ 17 Academician Lavrentiev Ave., Novosibirsk, 630090, Russian Federation \\ ${ }^{2}$ Novosibirsk State University \\ 1 Pirogov Str., Novosibirsk, 630090, Russian Federation \\ ${ }^{3}$ German Archaeological Institute, Eurasian Department \\ 2-6 Im Dol, Building II, 14195, Berlin, Germany \\ molodin@archaeology.nsc.ru, sabine.reinhold@dainst.de,l.mylnikova@yandex.ru \\ nenaxoffsurgut@mail.ru,sekretariat.eurasien@dainst.de
}

\title{
RADIOCARBON DATES OF THE TARTAS-1 NEOLITHIC COMPLEX (EARLY NEOLITHIC IN BARABA)
}

Purpose. The Neolithic sites of the Baraba forest-steppe have always been in the focus of the archaeological scientific community. In the current millennium, the study of the Neolithic settlements and cemeteries significantly enriched the science with new, sometimes completely unexpected discoveries, such as a version that some artifacts found in the area belong to the Artynskaya culture, singled out by L. L Kosinskaya, or a discovery of a series of burial complexes of developed Neolithic with original funeral practice at Vengerovo-2A and Avtodrom-1 sites, etc. The concept of historical and cultural development in the region started to develop at a new level. In this respect, we reviewed the descriptions of the sites with flat-bottomed Neolithic ceramics, which their discoverers had identified as complexes of the Boborykinskaya culture. Our goal was to prove that the identification was misleading.

Results. We can summarise that the Neolithic complex at the time-based and multicultural site Tartas-1 was opened as a result of using solid excavations with the orientation toward magnetic surveying. The complex includes two structures and a set of deep and large in diameter pits used probably for sifting fish stocks and waterfowl. In construction number 6, a thermo-technical structure used as a smokehouse was fixed. Fragments of ceramics and three vessels with flat-bottomed morphology of their form and ornamentation, similar to dishes from Avtodrom-2/2, were found in residential structures and pits. In order to date and describe the artifacts in more details, we used radiocarbon analysis. Eight measurements were taken. The dates were obtained by analyzing the bones of animals. All samples were taken from the stratigraphically flawless cultural horizons of both buildings and pits. The earliest were three indicators referring to the system of pits number 991 . According to Sigma 1, the first is determined within 7063-6838 years BC, the second - 7025-6710 years BC, and the third - 6658-6596 years BC. If we focus on Sigma 2, all three dates have a common ground. Four more dates show very close indicators, and according to sigma 2 they are correlated. For structure 7, the first horizon in Sigma 1 shows the exponents of 6470-6446 years BC, the second - 6477-6260 years BC, and the third horizon dates back to 6375-6260 years BC. For pit number 1220, dates of 6240-6108 BC were obtained. A bone sample taken from the filling of dwelling number 6 gave a date of 5977-5888 years BC, according to Sigma 1. Thus, in terms of dates, all 8 samples taken from the complex under investigation fit within the limits of the $7^{\text {th }}$ millennium BC, touching the boundaries of the $6^{\text {th }}$ and $8^{\text {th }}$ millennium BC. At Vengerovo-2, a sample of the animal bone from the Neolithic pit was dated by Sigma 1 as 6426-6385 years BC, and according to Sigma $2-6440-6266$ years BC. This series of radiocarbon dates proved to be incomparable with the dating of similar ceramics from the Avtodrom-2/2 settlement obtained by direct dating: the latter shows an age of $5460 \pm 100 ; 5967 \pm 100 ; 5884 \pm 100 \mathrm{BP}$. Their calibrated values range between the last quarter of the $6^{\text {th }}$ and the middle of the $5^{\text {th }}$ millennium BC.

Conclusion. The complex with flat-bottomed dishes of the Tartas-1 site belongs to the earliest stage of the Neolithic period and can be qualified as the early Neolithic of the Baraba forest-steppe. This conclusion coincides with the chronological evaluation of the Neolithic monuments in West Siberian North. Calibrated radiocarbon dates place our group of early Neolithic sites within the range between the end of the $7^{\text {th }}$ and the first half of the $6^{\text {th }}$ millennium BC. In general, Neolithic of 
Western Siberia (taiga and forest-steppe zone) with flat-bottomed ceramics should be assessed as a phenomenon of a general historical and stadial nature. Its origin is considered autochthonous.

Keywords: Baraba forest-steppe, early Neolithic, flat-bottomed ware, radiocarbon dating.

\section{References}

Besprozvannyi E. M., Pogodin A. A. Mezolit severa Zapadnoi Sibiri: itogi izucheniya [Mesolithic of the North of Western Siberia: Results of the Study]. Sovremennye problemy arkheologii Rossii. Mater. Vserossiiskogo arkheologicheskogo s'ezda [Modern problems of Russian archaeology. Materials of the All-Russian Archaeological Congress]. Novosibirsk, IAE SB RAS, 2006, vol. 1. p. 168. (in Russ.)

Bobrov V. V., Marochkin A. G. Artynskaya kul'tura [The Artynskaya Culture]. Trudy III (XIX) Vserossiiskogo arkheologicheskogo s'ezda [Proceedings of the III (XIX) All-Russian Archaeological Congress]. St. Petersburg, Moscow, Velikii Novgorod, 2011, vol. 1, p. 106-108. (in Russ.)

Bobrov V. V., Marochkin A. G. Boborykinskii kompleks iz Baraby: problema istoricheskoi interpretatsii [The Boborykinsky Complex from Baraba: on Historical Interpretation]. Vestnik TGU. Istoriya [Bulletin of Tomsk State University. History], 2013, no. 3 (23), p. 211-215. (in Russ.)

Bobrov V. V., Marochkin A. G., Yurakova A. Yu. Keramika artynskoi pozdneneoliticheskoi kul'tury (po materialam poseleniya Avtodrom 2) [Ceramics of the Late Neolithic Artynskaya Culture (Based on the Autodrome 2 Settlement Materials)]. Kul'tura kak sistema $v$ istoricheskom kontekste: opyt Zapadno-sibirskikh arkheologo-etnograficheskikh soveshchanii [Culture as a system in the historical context: experience of Western Siberian archaeological and ethnographic meetings]. Tomsk, Agraf-Press, 2010, p. 113-116. (in Russ.)

Bobrov V. V., Marochkin A. G., Yurakova A. Yu. Poselenie boborykinskoi kul'tury Avtodrom 2/2 (severo-zapadnye raiony Barabinskoi lesostepi) [Settlement of Boborykinskaya Culture Autodrome 2/2 (north-western areas of the Baraba forest-steppe]. Vestnik arkheologii, antropologii $i$ etnografii [Bulletin of Archaeology, Anthropology and Ethnography]. Tyumen', IPOS SO RAN Publ., 2012, no. 3 (18), p. 4-13. (in Russ.)

Bobrov V. V., Marochkin A. G., Yurakova A. Yu. Issledovaniya poselencheskikh i pogrebal'nykh kompleksov epokhi neolita na pamyatnike Avtodrom-1 v Barabinskoi lesostepi v 2015 godu [Studies of Settlement and Funerary Complexes of the Neolithic Age at the Autodrome-1 Site in the Baraba Forest-Steppe in 2015]. Problemy arkheologii, etnografii, antropologii Sibiri i sopredel'nykh territorii [Issues of archaeology, ethnography, anthropology of Siberia and adjacent territories]. Novosibirsk, IAE SB RAS, 2015, vol. 22, p. 7-11. (in Russ.)

Bobrov V. V., Marochkin A. G., Yurakova A. Yu. Poselenie artynskoi kul'tury Avtodrom-2 pamyatnik pozdnego neolita $\mathrm{v}$ Barabinskoi lesostepi [Settlement of the Artynskaya Culture Avtodrom-2 (Late Neolithic Site in the Baraba forest-steppe]. Arkheologiya, ehtnografiya $i$ antropologiya Evrazii [Archaeology, Ethnography and Anthropology of Eurasia], 2017, vol. 45, no. 1, p. 49-61. (in Russ.)

Bobrov V. V., Yurakova A. Yu. Boborykinskii kompleks v neolite Barabinskoi lesostepi [Boborykinsky Complex in the Neolithic of the Baraba Forest-Steppe]. Trudy IV (XX) Vserossiiskogo arkheologicheskogo s'ezda v Kazani [Proceedings of the IV (XX) All-Russian Archaeological Congress in Kazan]. Kazan', Otechestvo Publ., 2014, vol. 1, p. 211-214. (in Russ.)

Chemyakin Yu. P. Okhrannye raskopki na poselenii Barsova Gora II/9, ili Dvadtsat' let spustya [Security Excavations at the Settlement Barsova Gora II/9, or Twenty Years Later]. Khanty-Mansiiskii avtonomnyi okrug $v$ zerkale proshlogo [Khanty-Mansi Autonomous Area in the mirror of the past]. Tomsk, Khanty-Mansiisk, TSU Publ., 2009, p. 198-213. (in Russ.)

Chemyakin Yu. P. Radiouglerodnye daty pamyatnikov Barsovoi Gory [Radiocarbon Dates of the Barsova Gora Monuments]. Voprosy arkheologii Urala [Issues of Archeology of the Urals]. Ekaterinburg, Surgut, Magellan Publ., 2011, vol. 26, p. 247-249. (in Russ.)

Drozdov N. I. Paleograficheskie i ekologicheskie usloviya zhizni cheloveka v Severnom Priangar'e v kontse pleistotsena-golotsena [Paleographic and Ecological Conditions of Human Life in the Northern Angara Region at the End of the Pleistocene-Holocene]. Osobennosti estestvennogeograficheskoi sredy $i$ istoricheskie protsessy v Zapadnoi Sibiri [Features of the natural-geogra- 
phical environment and historical processes in Western Siberia]. Tomsk, TSU Publ., 1979, p. 3134. (in Russ.)

Drozdov N. I. Problemy i perspektivy arkheologicheskogo izucheniya basseina Severnogo Eniseya i Severnoi Angary [Issues and Perspectives of Archaeological Study in the Basin of the Northern Yenisei and the Northern Angara]. Problemy issledovaniya kamennogo veka Evrazii [Issues of the Stone Age of Eurasia]. Krasnoyarsk, KSPU Publ., 1984, p. 10-14. (in Russ.)

Drozdov N. I. Sovremennoe sostoyanie i vozmozhnosti razlichiya stratigrafii golotsena v Severnom Priangar'e [The Current State and Possibilities of the Difference in the Holocene Stratigraphy in the Northern Angara Area]. Priroda i khozyaistvo Krasnoyarskogo kraya [Nature and Economy of the Krasnoyarsk Territory]. Krasnoyarsk, KSPU Publ., 1985, p. 36-39. (in Russ.)

Gadzhchieva E. A. Neolit basseina r. Kondy [Neolithic in the Basin of the River Kondy]. Cand. histor. sci. syn. diss. St. Petersburg, 1993, 18 p. (in Russ.)

Gening V. F., Petrin V. T. Pozdnepaleoliticheskaya epokha na yuge Zapadnoi Sibiri [The Late Paleolithic Age in the South of Western Siberia]. Novosibirsk, Nauka, 1985, 88 p. (in Russ.)

Gening V. F., Petrin V. T., Kosinskaya L. L. Pervye poseleniya epokhi pozdnego paleolita i mezolita v Zapadnoi Sibiri [The first Settlements of the Late Paleolithic and Mesolithic in Western Siberia]. Iz istorii Sibiri [From the history of Siberia]. Tomsk, TSU Publ., 1973, vol. 5, p. 24-47. (in Russ.)

Ivas'ko L. V. Ukreplennoe poselenie kamennogo veka Kayukovo-2 [The fortified Settlement of the Stone Age Kayukovo-2]. Materialy i issledovaniya po istorii Severo-Zapadnoi Sibiri [Materials and research on the history of North-West Siberia]. Ekaterinburg, Ural State Univ. Publ., 2002, p. 7-25. (in Russ.)

Ivas'ko L. V. O kayukovskoi arkheologicheskoi kul'ture [About Kayukovo archeological culture]. Barsova Gora: drevnosti taezhnogo Priob'ya [Barsova Gora: antiquities of the taiga Ob region]. Ekaterinburg, Sugrut, Ural'skoe izd-vo Publ., 2008, p. 112-122. (in Russ.)

Jordan P., Gibbs K., Hommel P., Piezonka H., Silva F., Steele J. Moddeling the diffusion of pottery technologies across Afro-Eurasia: emerging insights and future research. Antiquity, 2016, no. 90351, p. 590-603.

Kiryushin Yu. F., Kiryushin K. Yu. Keramika boborykinskogo oblika s poselenii yugozapadnykh raionov Altaiskogo kraya [Pottery of the Boborykin Appearance from the Settlements of the Southwestern Regions of the Altai Territory]. Teoriya i praktika arkheologicheskikh issledovanii [Theory and practice of archaeological research]. Barnaul, Altay State Univ. Publ., 2016, no. 2 (14), p. 7-23. (in Russ.)

Kovaleva V. T. Poselenie Sumpan'ya III i problema kul'turno-khronologicheskoi atributsii pamyatnikov koshkinskogo tipa v taezhnoi zone Zapadnoi Sibiri [Settlement of Sumpania III and Cultural and Chronological Attribution of Koshkin-type Monuments in the Taiga Zone of Western Siberia]. Barsova Gora: drevnosti taezhnogo Priob'ya [Barsova Gora: antiquities of the taiga Ob region]. Ekaterinburg, Sugrut, Ural'skoe izd-vo Publ., 2008, p. 123-134. (in Russ.)

Kovaleva V. T., Zyryanova S. Yu. K voprosu o satyginskom tipe keramiki [On the Satygin Type of Ceramics]. Barsova Gora: drevnosti taezhnogo Priob'ya [Barsova Gora: antiquities of the taiga Priobye]. Ekaterinburg, Sugrut, Ural'skoe izd-vo Publ., 2008, p. 135-145. (in Russ.)

Kosinskaya L. L. Pozdneneoliticheskaya stoyanka Artyn na Srednem Irtyshe [Late Neolithic Site Artyn in the Middle Irtysh]. Arkheologicheskie issledovaniya Severa Evrazii [Archaeological Studies of the North of Eurasia]. Sverdlovsk, Ural. State Univ. Publ., 1982, p. 18-27. (in Russ.)

Kosinskaya L. L. Glava 1. Arkheologicheskie kul'tury Yamala. 1.1. Kamennyi vek severa Zapadnoi Sibiri [Chapter 1. Archaeological cultures of Yamal. 1.1. Stone Age of the North of Western Siberia]. Istoriya Yamala. Tom 1. Yamal traditsionnyi. Kniga 1. Drevnie kul'tury i korennye narody [History of Yamal. Volume 1. Yamal is a traditional one. Book 1. Ancient cultures and indigenous peoples]. Ekaterinburg, Basko Publ., 2010a, p. 22-47. (in Russ.)

Kosinskaya L. L. Syr'evaya strategiya i kamneobrabotka kak aspekty kul'turnoi adaptatsii (po materialam neoliticheskikh pamyatnikov severa Zapadnoi Sibiri) [Raw Material Strategy and Stone Processing as Aspects of Cultural Adaptation (based on materials of Neolithic monuments of the north of Western Siberia)]. Ural'skii istoricheskii vestnik [Ural Historical Herald]. Ekaterinburg, Izd-vo Institut istorii i arkheologii URO RAN Publ., 2010б, no. 2 (27), p. 13-25. (in Russ.) 
Kosinskaya L. L. Rannyaya grebenchataya keramika v neolite Zaural'ya [Early Comb-like Ceramics in the Neolithic Ural Area]. Ural'skii istoricheskii vestnik [Ural Historical Herald]. Ekaterinburg, Izd-vo Instituta istorii i arkheologii URO RAN Publ., 2014, no. 2 (43), p. 30-39. (in Russ.)

Kosintsev P. A., Bobkovskaya N. E., Besprozvannyi E. M. Radiouglerodnaya khronologiya arkheologicheskikh pamyatnikov taezhnoi zony Zapadnoi Sibiri [Radiocarbon Chronology of Archaeological Monuments of the Taiga Zone of Western Siberia]. Khanty-Mansiiskii avtonomnyi okrug v zerkale proshlogo [Khanty-Mansi Autonomous Area in the Mirror of the Past]. Tomsk, Khanty-Mansiisk, TSU Publ., 2004, vol. 2, p. 17-32. (in Russ.)

Marchenko Zh. V. Radiouglerodnaya khronologiya arkheologicheskikh pamyatnikov epokhi neolita i rannego metalla Barabinskoi lesostepi [Radiocarbon Chronology of Archaeological Monuments of the Neolithic and Early Metal Age of the Barabinsk Forest-Steppe]. Rol' estestvennonauchnykh metodov $v$ arkheologicheskikh issledovaniyakh [The role of natural scientific methods in archaeological research]. Barnaul, ASU Publ., 2009a, p. 140-143. (In Russ)

Marchenko Zh. V. Kul'turnaya prinadlezhnost', khronologiya i periodizatsiya arkheologicheskikh pamyatnikov srednego techeniya r. Tary (epokha neolita i bronzy) [Culture Attribution, Chronology and Periodization of Archaeological Monuments in the Middle Tara River (Neolithic and Bronze Age)]. Cand. histor. sci. syn. diss. Novosibirsk, 2009b, 26 p. (in Russ.)

Merts V. K. Boborykinskii kompleks poseleniya Borly (Severo-Vostochnyi Kazakhstan) [Boborykinsky Complex of the Borly Settlement (North-East Kazakhstan]. Trudy IV (XX) Vserossiiskogo arkheologicheskogo s'ezda v Kazani [Proceedings of the IV (XX) All-Russian Archaeological Congress in Kazan]. Kazan', Otechestvo Publ., 2014, vol. 1, p. 297-301. (in Russ.)

Merts V. K. O keramike boborykinskogo tipa iz neolit-eneoliticheskikh kompleksov Severnogo Kazakhstana [On Ceramics of the Boborykin Type from the Neolithic-Eneolithic Complexes of Northern Kazakhstan]. Drevnii Turgai i Velikaya step': chast'i tseloe. Sbornik statei posvyashchennykh 70-letiyu V. N. Logvina [Ancient Turgai and the Great Steppe: part and the whole. Collection of articles dedicated to the $70^{\text {th }}$ anniversary of $V$. N. Logvin]. Kostanai, Almaty, Institut arkheologii im. A. Kh. Margulana Publ., 2015, p. 267-272. (in Russ.)

Molodin V. I., Nenakhov D. A., Nesterova M. S., Durakov I. A., Vasil'ev S. K. Original'nyi proizvodstvennyi kompleks na Tartase-1 (Barabinskaya lesostep') [Original Production Complex on the Tartas-1 Site (Barabinsk Forest-Steppe)]. Problemy arkheologii, etnografii, antropologii Sibiri $i$ sopredel'nykh territorii [Problems of archaeology, ethnography, anthropology of Siberia and adjacent territories]. Novosibirsk, IAE SB RAS Publ., 2015, vol. 21, p. 326-331. (in Russ.)

Molodin V. I., Nesterova M. S., Myl'nikova L. N. Pogrebal'nye kompleksy epokhi neolita Vengerovo-2A (yug Zapadno-Sibirskoi ravniny): rezul'taty mul'tidistsiplinarnykh issledovanii [Burial Complexes of the Neolithic Age of the Vengerovo-2A Site (South of West Siberian Plain): results of multidisciplinary research]. Arkheologiya, ehtnografiya $i$ antropologiya Evrazii [Archaeology, Ethnography and Anthropology of Eurasia]. Novosibirsk, IAE SB RAS Publ., 2016, vol. 44, no. 2, p. 30-46. (in Russ.)

Morozov V. M., Stefanov V. I. Amnya-1 - drevneishee gorodishche Severnoi Evrazii? [Is Amnya-1 the Most Ancient Settlement of Northern Eurasia?]. Voprosy arkheologii Urala [Issues of archaeology of the Urals]. Ekaterinburg, Ural State Uni., 1993, vol. 21, p. 161-163. (in Russ.)

Mosin V. S. Neolit lesostepnogo Zaural'ya i Priirtysh'ya: noveishie issledovaniya i periodizatsiya [Neolithic of the Forest-Steppe Trans-Ural Region and the Irtysh Area: latest research and periodization]. Vestnik Kemerovskogo gosudarstvennogo universiteta [Bulletin of the Kemerovo State University]. Kemerovo, KSU Publ., 2015, no. 2 (62), p. 108-113. (in Russ.)

Mosin V. S. Sotsiokul'turnoe prostranstvo v pozdnem kamennom veke [Sociocultural Space in the Late Stone Age]. Vestnik Permskogo universiteta. Istoriya [The Bulletin of the Perm University. History]. Perm', PSU Publ., 2016, vol. 1 (32), p. 19-27. (in Russ.)

Okladnikov A. P., Medvedev V. E. Issledovanie mnogosloinogo poseleniya Gasya na Nizhnem Amure [Research on the Multilayered Settlement Gasya on the Lower Amur]. Izvestiya Sibirskogo otdeleniya AN SSSR. Seriya obshhestvennyh nauk [News of the Siberian Branch of Academy of Sciences of the USSR. Series of Social sciences], 1983, vol. 1, no. 1, p. 93-97. (in Russ.)

Okladnikov A. P., Molodin V. I. Paleolit Baraby [Paleolith in Baraba]. Paleolit Sibiri [Paleolith of Siberia]. Novosibirsk, Nauka, 1983, p. 101-106. (in Russ.) 
Petrin V. T. Paleoliticheskie pamyatniki Zapadno-Sibirskoi ravniny [Paleolithic Monuments of West Siberian Plain]. Novosibirsk, Nauka, 1986, 142 p. (in Russ.)

Pogodin A. A., Besprozvannyi E. M. Novye issledovaniya kamennogo veka taezhnoi zony Zapadnoi Sibiri [New Research on the Stone Age of Western Siberia taiga zone]. 120 let arkheologii vostochnogo sklona Urala. Pervye chteniya pamyati V. F. Geninga. 42 noveishie otkrytiya ural'skikh arkheologov [120 years of archaeology of the east slope of the Urals. First readings in memory of V. F. Geninga. $42^{\text {nd }}$ latest discoveries of Ural archaeologists]. Ekaterinburg, Ural State Uni., 1999, p. 99-103. (in Russ.)

Stefanov V. I., Borzunov V. A. Neoliticheskoe gorodishche Amnya I (po materialam raskopok 1993 i 2000 godov [Neolithic Settlement Amnya I (on materials of excavations of 1993 and 2000)]. Barsova Gora: drevnosti taezhnogo Priob'ya [Barsova Gora: antiquities of the taiga Ob region]. Ekaterinburg, Sugrut, Ural'skoe izd-vo Publ., 2008, p. 105-107. (in Russ.)

Timofeev V. I., Zaitseva G. I. K probleme radiouglerodnoi khronologii neolita stepnoi i yuga lesnoi zony evropeiskoi chasti Rossii (obzor istochnikov) [On Radiocarbon Chronology of Neolithic Steppe and Southern Forest Zone of the Russia's European Area (review of sources)]. Radiouglerod $i$ arkheologiya [Radiocarbon and archaeology]. St. Petersburg, [without Publ.], 1997, vol. 2, p. 98108. (in Russ.)

Vasil'evskii R. S., Burilov V. V., Drozdov N. I. Arkheologicheskie pamyatniki Severnogo Priangar'ya [Archaeological Sites of the North Angara Region]. Novosibirsk, Nauka, 1988, 225 p. (in Russ.)

Vasil'evskii R. S., Drozdov N. I. Paleoliticheskie skul'pturnye izobrazheniya iz Vostochnoi Sibiri [Paleolithic Sculptural Images from Eastern Siberia]. Plastika i risunki drevnikh kul'tur [Plastics and drawings of ancient cultures]. Novosibirsk, Nauka, 1983, p. 59-65. (in Russ.)

Vasil'evskii R. S., Drozdov N. I. Skul'pturka mamonta iz Severnogo Priangar'ya [Sculpture of a Mammoth from the North Angara Region]. Priroda [Nature], 1988, no. 4, p. 46-48. (in Russ.)

Vybornov A. A. Neolit Volgo-Kam'ya [Neolithic of the Volgo-Kama Region]. Samara, SSPU Publ., 2008, 490 p. (in Russ.)

Vybornov A. A., Mosin V. S., Epimakhov A. V. Khronologiya Ural'skogo neolita [Chronology of the Ural Neolithic]. Arkheologiya, etnografiya i antropologiya Evrazii [Archaeology, Ethnography and Anthropology of Eurasia], 2014, no. 1 (57), p. 33-48. (in Russ.)

Yurakova A. Yu. Neolit Barabinskoi lesostepi i yuzhno-taezhnogo Priirtysh 'ya [Neolithic of the Barabinsk Forest-Steppe and Southern Taiga in the Irtysh Area]. Cand. histor. sci. syn. diss. Kemerovo, 2017, 30 p. (in Russ.)

Zakh V. A. K voprosu o boborykinskoi kul'ture [On the Boborykinskaya Culture]. Rol' Tobol'ska v osvoenii Sibiri [The Role of Tobolsk in exploring Siberia]. Tobol'sk, 1987, p. 11-13. (in Russ.)

Zakh V. A. Khronostratigrafiya neolita i rannego metalla lesnogo Tobolo-Ishim'ya [Chronostratigraphy of the Neolithic and Early Metal Age in the forest Tobol-Ishim Area]. Novosibirsk, Nauka, 2009, 320 p. (in Russ.) 